\title{
FINANCING FOR SUSTAINABLE DEVELOPMENT: SOLUTIONS OF WORLD SUMMIT ON SUSTAINABLE DEVELOPMENT
}

\author{
Thosapala Hewage \& B.M.S. Batagoda \\ Ministry of Envirchnent and Natural Resources
}

The World Summit on Sustainable Development (WSSD) held in Johannesburg, South Africa 2002 has given significant priority to finance and trade issues since funding has been identified as key constraints for the implementation of Agenda 21. The Summit adopted some ambitious programs specifically for poverty eradication such as halving the proportion of the world's people whose income is less than $\$ 1$ a day, proportion of pcople who suffer from hunger, proportion of people who are without access to safe drinking water and sanitation by 2015 . Obvious y, the implementation of all its decisions depends on the success of addressing development finance issues that covers a vast range, from official development assistance to tommercial loans by multilateral financial institutions and private banks, foreign direct invest ment, domestic credits, investment and government transfers. The objective of this paper is to investigate whether the WSSD presents a solution to the financing for sustainable cievelopment taking Sri Lanka as a case study.

The study observed that between 1992-2000 Official Development Assistant (ODA) has fallen steadily from $0.33 \%$ of donor country GNP to $0.22 \%$ although at the Earth Summit developed countries agreed to provide $0.7 \%$ of GNP as ODA. This decline has affected the least developed countries (LDCs), who are highly dependant on ODA, which constitutes on the average almost $90 \%$ of their tota ong term capital inflows. However during this period, Foreign Direct Investment (FDI) has significantly increased. FDI to developing countries has increased from US\$ 36 billion in 1991 to US\$ 185 billion in 1999 , bul declined to US\$ 175 billion in 2000 . This is however is only a small portion of the global FDI flows, which amounted to US\$ 1.1 trillion in 2000 . In $2000,80 \%$ of FDI went to only ten developing countries and LDCs attruted only $2.5 \%$ of all FDI flows to developing countries. In Sri Lanka, foreign direct investments have dropped from US\$ $129 \mathrm{Mn}$ in 1977 to US\$ $82 \mathrm{Mn} 2001$. Total outstarding forcign debt has rose from Rs. $235,358 \mathrm{Mn}$ in 1992 to Rs. 634,622 Mn in 2001. This indicates serious debt crises in developing countries, which is not a favorable condition for atuacting further FDI to developing countries.

At the same time measures taken by the international community to treat the excessive debt burdens of 41 heavily indebted poor ccuntries (HIPC) have not delivered the expected results. Thought the IMF and the World Bank have approved debt reduction programs for 22 countries in December 2000, only Uganda was able to clcar the prerequisitc the creditors. This evidently suggests that the proposed financing measures at the WSSD will also face implementation problems. Uiless all debtors and creditors work positively without demanding unreasonable prerequisite for debt relief measures, the objcctives of the WSSD cannot be achieved.

Proceedings of the Eighth Annual Forestry and Environment Symposium 2002 of the Department of Forestry and Environmental Science, University of Sri Jayewardenepura, Sri Lanka 